spent considering the recommendations of a Termite Sub-Committee which had been set up at an early stage of the Conference. These recommendations stressed the urgent need for research work on termites, particularly in the Colonies.

During the course of the Conference, delegates visited Whipsnade, Rothamsted Experimental Station, the Pest Infestation Laboratory of the Department of Scientific and Industrial Research at Slough and the new entomological Field Station of the Imperial College of Science and Technology at Silwood Park. These visits, combined with certain social occasions, served to give delegates that chance of informal discussion which is perhaps the most valuable part of a conference of this nature.

\section{FOSSIL FLORA OF KERGUELEN ISLAND}

$\mathrm{T}$ HE biological interest of Kerguelen Island (latitude $49^{\circ} \mathrm{S}$., longitude $69^{\circ} \mathrm{E}$.) has been well known to botanists since 1847, when the young Joseph Hooker, as junior surgeon in Ross's famous voyage to the Antarctic in the Erebus and Terror, contributed a description ${ }^{1}$ of the botany of this island gained as the result of the expedition's first winter in the southern hemisphere (May-July, 1840). The extreme poverty of the flora was its most noticeable feature, only eighteen species of flowering plants having been found by Hooker, and of these only eight covered any considerable expanse of ground. These included the remarkable endemic crucifer, Pringlea antiscorbutica (the Kerguelen Island cabbage), and a peculiar umbellifer related to the 'balsam bog' of the Falkland Islands. In comparable latitudes in the northern hemisphere much richer floras were known to occur, the vegetation of Spitsbergen, for example, containing records in 1847 of forty-five species of flowering plants on a comparable area. This, coupled with the isolated position of the island in the middle of the Antarctic Ocean, almost equidistant from South Africa and from Australia, the presence of the endemies and the vegetational affinity with the even more distant Falkland Islands (off Cape Horn), are all problems of lively plant-geographical interest to us as to Hooker. Problems of equal interest are those raised by the very marked changes of climate which have occurred in these now desolate latitudes in fairly recent geological time. Hooker himself was pro. foundly impressed by seeing not only coal but also fossilized tree trunks of considerable size (one is specifically mentioned by Ross as $7 \mathrm{ft}$. in circum. ference), although the existing vegetation cannot boast even a shrub, still less a tree, and this circumstance was certainly one of the more powerful reasons which predisposed him to the immediate acceptance of the idea of evolution when it came.

The fossil woods brought back by the Ross expedition were not further investigated until 1921, when Edwards ${ }^{2}$ of the British Museum identified them as coniferous. Shortly after this in 1934 Seward and Conway $^{3}$ identified araucarian twigs and cone scales in some macroscopic plant remains brought back by de la Rue in 1931. This material also contained the remains of a moss and some indeterminate fragments of dicotyledonous leaves and ferns.

An additional contribution is now available in the eighth part of vol. 2 (pp. 129-142) of the Reports of the British, Australian and New Zealand Antaretic Research Expedition of 1929-31, published at Adelaide, 1947, under the title of "Plant Microfossils from the Lignites of the Kerguelen Archipelago by Isabel C. Cookson" (price 4s. 6d.). This is one of the few applications of the pollen analysis technique to fossil floras of the southern hemisphere, and though carried out on very limited material the results add greatly to previous knowledge while holding out considerable hope of more to come.

As was to be expected from Seward and Conway and from Edwards, araucarian pollen predominates. This is, however, not the only gymnosperm present. Five distinguishable species, undoubtedly belonging to the Podocarpacere though of less certain generic identity within that family, are listed under the form genera of Disaccites (Podocarpidites), Polysaccites (Microcachryidites) and Disaccites (Phyllocladidites). Angiospermous pollen is also present though more sparingly, five species only being so far recorded, three of which appear to be dicotyledons and two mono. cotyledons. In contrast there are ten varieties of Pteridophyte spores, probably of ferns, but not identifiable generically. There are likewise two species of ascomycetous fruit body.

While the available information does not yet permit of a generalized palæoecological statement to be made of this most interesting region it seems clear that gymnosperms and ferns predominate in the lignites so far examined, the age of which is on that account thought to be Tertiary. It is greatly to be hoped that this work will be further extended by a systematic study of additional collections and through the whole thickness of the deposits.

${ }^{1}$ Ross, J. C., "A Voyage of Discovery and Research in the Southern and Antarctic Regions during the Years 1839-43" (London, 1847). ${ }^{2}$ Edwards, W. N., Ann. Bot., 35, 609 (1921).

${ }^{3}$ Seward, A. C., and Conway, V., Ann. Bot., 48, 715 (1934).

\section{BIOLOGY AND CONTROL OF THE PEA MOTH}

$\mathrm{T}$ HE pea moth, Laspeyresia nigricana, Steph., is a widely distributed pest of garden and field peas in Great Britain and central and southern Europe, while in North America it has spread to all main pea-growing areas. In England the most severe losses occur in the pea-producing counties of Lincoln, Essex and Kent. D. W. Wright and Q. A. Geering, of the Horticultural Research Station and School of Agriculture, Cambridge, have published a useful paper on the biology and control of the pea moth (Bull. Entom. Res., 39, pt. 1, 57 ; 1948).

It appears that the moths show no special preference for ovipositing on or near the flowers or pods. The larva feeds on the young seeds in the pod and bores a hole through the pod-wall for the purpose of reaching its food. The hole heals over, however, in a few days, leaving a small blister. When fully grown the larva spins a thin, web-like cocoon imme. diately below the soil surface, wherein pupation takes place. The majority of the moths emerge before the end of July in the following year. Normally there seems to be only a single generation of this insect in Britain.

The trials that were carried out indicate that different varieties of peas differ widely in their 
susceptibility to attack. Furthermore, the infestation on the varieties is influenced by the amount of foliage cover that is available, the heaviest attacks being where the cover is most dense. Certain varieties of peas are well known to escape much of the severity of pea moth attack if sown early. Also, it appears that crops can be grown almost free from infestation if sown in the latter half of June or in July, since they will mature after the flight period of the moth.

It is recommended that the residue of crops picked green should be removed immediately and fed to stock, made into manure or ensilaged. This prevents the caterpillars from maturing in the seeds and pupating in the soil. Experiments using D.D.T. as an emulsion, or as a suspension, showed that considerable reduction in attack could be obtained with the concentration at 0.5 per cent by weight of D.D.T. It was found that the spray should be applied before egg-hatching has begun which, for sowings made in late April and in May, would be about 7-10 days after the first flowers appear on the crop.

\section{APPOINTMENTS VACANT}

ApPLICATIONS are invited for the following appointments on or before the dates mentioned:

ASSISTANT LECTURER (with high mathematical qualifications) IN THE DEPARTMENT OF MATHEMATICS-The Clerk to the Governors, Chelsea Polytechnic, Manresa Road, London, S.W.3 (August 28). HISTOLOGICAL TECHNICLAN-Prof. A. Durward, Department of HISTOLOGICAL THCHNICLAN-Prof. A. Durward, Department
Anatomy, Medical School, The University, Leeds 2 (August 30).

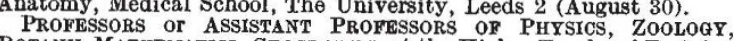
PROFESSORS or ASSISTANT PROFESSORS OF PHXSICS, ZOOLOGY,
BOTANY, MATHEMATIIS, GEOGRAPHY, at the Higher Teachers' Training BotaNY, Mathematics, GEOGRAPHY, at the Higher Teachers' Training
College, Baghdad ; PROFESSOR or ASSISTANT PROFESSOR of MATHEMATICS, ASSISTANT PROFESSOR OF PHYSICS, PROFESSOR OF BIOLOGY, Matics, ASSISTANT PROFESSOR OF PHYSICS, PROFESSOR OF BIOLOGY,
LECTORER OR ASSISTANT PROFESSOR OF PSYCHOLOGX, PROFESSOR OF CHEMISTRY, at the Queen Alivah College; DEAN, and a PROFESSOR OF ELECTRICAL ENGINEKRING, at the College of Engineering; ASSISTOF ELECTRICAL ENGINEKRING, at the College of Engineering; Assist-
ANT PROFESSOR OF ECONOMIC STATISTICS, at the College of Commerce -The Cultural Attaché, Iraqi Embassy, 22 Queen's Gate, London, S.W.7 (August 31).

ASSISTANT IN BOTANY-The Secretary, The University, Aberdeen (August 31).

H.M. INSPBCTORS OF FACTORIES-The Secretary, Ministry of Labour
and National Service (0.E.11), 80 Pall Mall, London, S.W.1 (August 31).

Prinorpal, a Profressor of Civil Engineering, a Profisssor of MECHANICAL ENGINEERING, and a PROFESSOR OF ELECTRICAL ENGINEERING, at the Government College of Engineering, Dacca-
The High Commissioner for Pakistan, 14 Fitzhardinge Street, Londion, W.I (August 31)

SENIOR PROFESSIONAL OFHCER (Ceramic and Refractory Research), University of the Witwatersrand, Johannesburg-The Director,
Government Metallurgical Laboratory, c/o Mr. Victor Reid, South Government Metallurgical Laboratory, c/o Mr. Victor Reid
Africa House, Trafalgar Square, London, W.C.2 (August 31).

Chemist-IN-CHARaE at the Royal Ordnance Factory, Pembrey, under the Ministry of Supply-The Ministry of Labour and National Service, Technical and Scientific Register, K Section, York House, Kingsway, London, W.C.2, quoting F.606/48A (August 31).

CHEMISTS in certain Explosive Factories in the Directorate of Ordnance Factories under the Ministry of Supply-The Ministry of Section, York House, Kingsway, London, W.C.2, quoting F.605/48A (August 31).

LABORATORY ASSISTANT (Grade I) IN THE DEPARTMENT OF ZOOLOGY The Secretary, Bedford College for Women, Regent's Park, Iondon, N.W.1 (September 4).

LEOTURER IN AGRICULTURE, a LECTURER IN DAIRYING, an ASSISTANT LECTURER IN BOTANY, a LECTURER IN HORTICULTURE, and a HORTICULTURAL ADVISER AND LECTURER (junior post)-The Secretary, West of Scotland Agricultural College, 6 Blythswood Square, Glasgow, C.2 (September 4).

LECTURER (Grade II or Grade III) IN ELECTRICAI GNGINEERINGThe Secretary and Registrar, The University, Bristol (September 4). LECrORER IN INORGANIC CHEMISTRY-The Registrar, King's College, Newcastle-upon-Tyne (September 11).

SENIOR ORGANIC CHEMIST in the biochemistry section for work on the organic constituents of fruit-bearing plants - The Secretary, East Malling Research Station, East Malling, Maidstone, Kent (September 11).

HEAD OF THE INSTRUMENT DIVISION at the National Institute for Medical Research, Hampstead-The Secretary, Medical Research Council, 38 old Queen Street, London, S.W.1 (September 11).

ASSISTANT LRCTURRR, preferably with some experience in Radar esearch-The Registrar, University College, Hull (September 13). INA-The Professor of Civil Engineering, Queen's University, Belfast (September 15).
MUllard REAdERSHIP IN ELECTRONics at the Imperial College of Science and Technology-The Academic Registrar, University of London, Senate House, London, W.C.1 (September 15).

Proprssor OF POWER STATIONS in the Mechanical Engineering Department of the Faculty of Engineering, Farouk I University Alexandria-The Director, Egyptian Education But tardens, London, W.1 (September 15).

SENIOR LEOTURER IN ELEOTRICAL ENGINEERING at the University f Melbourne-The Secretary, Universities Bureau of the British mpire, 8 Park Street, London, W.1 (September 15)

PROFESSOR OF BOTANY at Fouad I University, Cairo-The Director Egyptian Education Bureau, 4 Chesterfleld Gardens, London, W. (September 15)

INSPBCTORS (Salmon and Freshwater Fisheries) IN THE MINISTRY of AGrioulture AND Fisheries-The Secretary, Civil Service Commission, 6 Burlington Gardens, London, W.1, quoting No. 2258 (September 16).

SENIOR EXPERIMRNTAX OFFICER in an experimental research establishment of the Ministry of Supply, near Salisbury-The Secretary, Civil Service Commission, Scientific Branch, 27

London, W.1, quoting No. 2256 (September 17).
RESEAROH FELLOWSHIP IN THE TURNER DENTAL School-The Registrar, The University, Manchester 13 (September 18).

SIMON VISITING PROFESSOR, and SIMON RESEARCH FELLOWSHIPS, for Advanced Study or Research in the Social Sciences-The Registrar, The University, Manchester 13 (September 29).

AGRICULTURAL ECONOMISTS (3, one at each College)-The Secretary, West of Scotland Agricultural College, 6 Blythswood Square, Glasgow C.2; The Secretary, Edinburgh and East of Scotland College of Agriculture, 13 George Square, Edinburgh 8; The Secretary, North (September 30).

Lecturer (ungraded) IN Veterinary PARASITology-The Registrar, Schools of Tropical Medicine and Veterinary Science, The University, Liverpool (September 30)

ASSISTANT EXAMINERS IN THE PATENT OFFICE under the Board of Trade-The Secretary, Civil Service Commission, 6 Burlington Gardens, London, W.1, quoting No. 45A (September 30).

Chatr of Meohanical Engineering, a Senior Lecturer in ZOOLOGY, a LECTORER IN ZOOLOGY, and a TBCHNICIAN IN THE DRPARTMENT OF ZOOLOGY, at Auckland University College, New Zealand -The Secretary, Universities Bureau of the British Empire, 8 Park Street, London, W.1 (October 1).

READERSHIP IN CIVIL ENGINEERING at King's College-The Academic Registrar, University of London, Senate House, London, W.C.1 (October 1).

CHAIR OF ORGANIO CHEMISTRY at the Imperial College of Science and Technology-The Academic Registrar, University of London, Senate House, London, W.C.1 (October 4).

CURATOR OF THE AUCKLAND ZOOLOGICAL PARK-The Office of the High Commissioner for New Zealand, 415 Strand, London, W.C.2 (Auckland, October 29)

LECTURER IN TROPICAL HYGIENE-The Dean, Liverpool School LECTURER IN TROPICAL HYGIENE-The Dean, Liverpool School
of Tropical Medicine, Pembroke Place, Liverpool 3, endorsed 'Lectureship in Tropical Hygiene' (October 31).

FELLOWSHIPS and ScHOLARSHIPS for the advancement of Extraction Metallurgy-The Secretary, Nuffield Foundation, 12-13 Mecklenburgh Metallurgy-The Secretary, Nuffield Foundation, 12-13 Mecklenburgh
Square, London, W.C.1 (November 1).

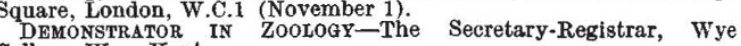
College, Wye, Kent.

Plant Physiologist to study the physiology of cocoa, with special reference to water, nutrient and light requirements, and PLAN BREEDERS to undertake the selection and breeding of cocoa types and
varieties and progeny trials, at the West African Cocoa Research varieties and progeny trials, at the West African Cocoa Research
Institute, Gold Coast-The Director of Recruitment, Colonial Offce, Institute, Gold Coast-The Director of Recruitment, Coloni
Sanctuary Buildings, Great Smith Street, London, S.W.1. anctuary Buildings, Great Smith Street, London, S.W.1.
SCTENTIFIC OFFICER to deal with administrative aspects of research SoTENTIFIC OFFICER to deal with administrative aspects of research -The National Coal Board, Establishments (General) Branch.

GRADUATR (or equivalent) as ASSISTANT IN ENQUIRY LABORATORY dealing with works problems submitted by member flrms-Th Printing, Packaging and Allied Trades Research Association, Randal Road, Leatherhead, Surrey.

HONOURS GRADUATE for work on engineering applications of fluid mechanics-The British Hydromechanics Research Association, 79 Petty France, London, S.W.1.

LABORATORY ASSISTANT (Grade II) for hygiene and bacteriology department - The Secretary, King's College of Household and Social Science, Campden Hill Road, London, W.8.

ScIENTISTS with research and practical experience in (a) COAL MrNING (Ref. TT/70), and (b) COAL CHEMISTRX, analytical work, metallurgy or coal tar (Ref. TT/71) - The National Coal Board,
Establishments (General) Branch, Hobart House, Grosvenor Place, London, S.W.1, quoting appropriate Ref. No.

LECTURER IN MATHEMATICS at the University of Otago, DunedinThe High Commissioner for New Zealand, 415 Strand, London, W.C.2. CHEMIST by the East African Industrial Management Board, Nairobi, Kenya--The Crown Agents for the Colonies, 4 Millbank London, S.W.1, quoting M.N.21789/3E.

LABORATORY TECHNICIAN (male) IN THE DEPARTMENT OF CHEMICAL Pathology - The Secretary, Medical School, Guy's Hospital, London Bridge, London, S.E.1.

MANAGING CHEMIST to take charge of the Metallurgical Development laboratories in the Department of Atomic Energy at Spring. flelds Factory, Salwick, Preston, a CHEMIST-IN-CHARGE (must have extensive metallurgical knowledge with experience in modern methods of metallurgical investigation), and CHEMISTs to supervise experi. mental work related to the metallurgical development involved in Supply, Department of Atomic Energy, Risley, Warrington, Lancs. LECTURER IN CIVIL ENGINEERING, and a LECTURER IN MECHANICAL
ENGINERRING-The Clerk to the Governing Body, Battersea Poly. technic, Battersea, London, S.W.11.

echnic, Battersea, London, S.W.11.
AssistanT DIRECTOR (Metallurgical Development) IN THE DEPART. ASSISTANT DIRECTOR (Metalurgical Development) IN THE DEPART-
MENT OF ATOMIC ENERGY, Risley-The Staff Section, Ministry of Supply, Department of A tomic Energy, Risley, Warrington, Lancs. 